\title{
給油施設操業スケジューリング*
}

阿瀬始**. 茨木 俊秀***

\section{Scheduling of Valve Operations in Fuel Supply Facilities*}

Hajime $\mathrm{AsE}^{* *}$ and Toshihide IBARAKI ${ }^{* * *}$

\begin{abstract}
In the fuel supply facilities where fuels are unloaded from tankers to tanks and supplied through pipelines, reducing the number of valve operations is important to improve the efficiency of facility utilization. This is a combinatorial optimization problem that asks to minimize the number of changing the assignment patterns of tank groups to berths. We propose here an effective heuristic algorithm which exploits the special structure of the problem. Computational results indicate that this can be used as a scheduler in real-world supply facilities.
\end{abstract}

\section{1.はじめに}

本論文の対象とする給油施設とは，タンカーで運ばれ てきた油をバースから揚油し, 施設内のタンクに貯蔵後, パイプラインを通して供給先へ送油するための設備であ る、給油施設における操業スケジューリングでは, 供給 先からの送油要求と, 送油要求に対して決められた配船 計画に基づき，タンクの受入れ/払出し順序の約 1 週間 から 1ヶ月の計画を作成することが求められる.

Fig. 1 はこの給油施設の構成を示したものである.夕 ンカーで運ばれてきた油を揚油して施設内のタンクに貯 蔵するためには, タンカーを複数あるうちの適当なバー スに着船させ, 揚油配管上のいくつかのバルブを切り換 えて，揚油配管を通してバースと目的のタンク群とを接 続しなければならない。あるバースとタンク群を接続す るためには，そのバースとタンク群の対応関係を実現す るバルブを開くだけでなく，そのバースあるいはタンク 群がそれぞれすでに別のタンク群あるいはバースにつな がっていた場合にはそれらの対応関係を実現していたバ ルブを閉じなければならない.その結果, これらのバル

* 原稿受付 1997 年 2 月 3 日

** NKK (株) NKK Corp.; 2-1 Suehiro-cho, Tsurumi ward, Yokohama city, Kanagawa 230-8611, JAPAN

*** 京都大学 大学院. 情報学研究科 Graduate School of Informatics, Kyoto University; Yoshida Honmachi, Sakyo ward, Kyoto city, Kyoto 606-8317, JAPAN

Key Words: fuel supply facility, scheduling, graph coloring, maximal clique, heuristic algorithm.
ブの設定にはかなりの手間がかかるのが実情である。し たがって，いったんある設定で運用を始めると，その日 はできるだけ設定変更はしたくないという強い要求があ る、そこで, 各日のスケジュールにおいて, バースと夕 ンク群の対応関係の変更回数を最小とすることが要請さ れる。

本研究はこの目的を達成するタンク繰りスケジューリ ングシステムの開発を目指したものであり，所期のシス テムを開発することができたので, 以下にその内容を述 ベる.

\section{2. 給油施設操業スケジューリング問題}

\section{1 給油施設の概要}

給油施設は Fig. 1 に示すように, タンカーが到着して 接岸できるための $K$ 基のバース，陸揚げした油を貯蔵す るための $M$ 群のタンク群, 油を供給先へ送るための $L$ 系統のパイプラインからなる. 各タンク群は一般に同じ 容量の複数のタンクを有している。さらに, 油をバース から陸揚げする設備や供給先へ油を送り出すためのポン プ, バースとタンク, タンクとパイプラインを結ぶ施設内 配管や経路切換えのためのバルブなどを有する. 各バー スは揚油配管系統によりどのタンク群にも接続可能であ る. 本論文では $K \leqq M$ として議論を進めるが， $K>M$ の場合への一般化も可能である. 受け入れるべきタンク を切り換えるとき, 切換え先のタンクが元のタンクと同 


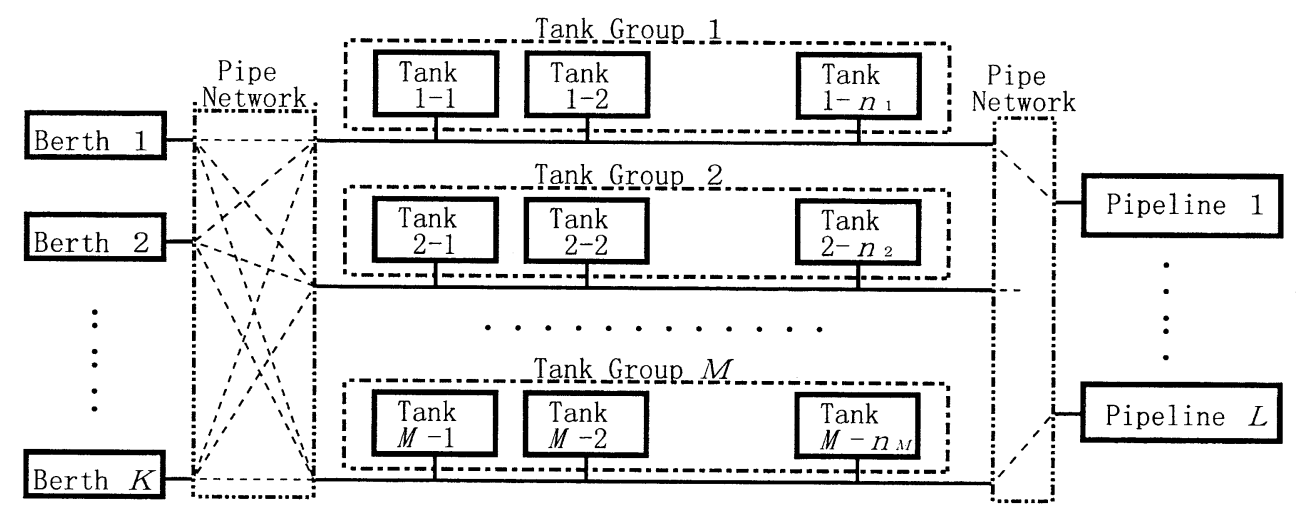

Fig. 1 Fuel supply facility

一タンク群内であれば，その切換えは短時間でできるの で操業上は支障をきたさない。それに反して，それらが 異なるタンク群に属するときは, バースとタンク群を結 ぶ施設内配管のいくつものバルブを切り換えることが必 要となり, 非常に時間がかかる. とくにこの切換えが揚油 中に発生すると, タンカーの出航を遅らせることになる.

また，バースは着栈可能なタンカーの積載量によって

$J$ 個のグループに分けられる. 各バースの揚油速度は等 しいとする.

\section{2 タンクの運用方法}

各タンクはいったん受入れを始めたら, 途中で受入れ を中断することなく, 満になるまで油を受け入れ続ける. ただし, 満になる前に揚油が終了した場合は, まだ満に なっていないが受入れ終了（中断）になる。満になって 定められた静置時間 (24 時間) 以上経過すると払出しが 可能となる. 払出しは空になるまで行い, その後再び定 められた静置時間 (3 時間) 以上経過すると受入れ可能 となる. 各タンクにおける受入れあるいは払出しの作業 がそれぞれ満あるいは空になる前に中断した場合は，そ のタンクの次の作業は中断した作業の継続となり, 再開 時の静置は必要でない.

\section{3 操業スケジューリング}

給油施設における操業スケジューリング1)とは, 供給 先からの送油要求と, 送油要求に対してあらかじめ決め られた配船計画を入力として, タンクの受入れ／払出し 順序の 1 週間-1ヶ月間の計画を作成することである.

\section{3. 問題の分析と定式化}

1 日単位で見ると, 配船計画によってその日に到着する タンカー (複数隻) の名称と到着時刻が決まっているの で, その日の各揚油の揚油時間帯と揚油量が決まる。ま た, 供給先からの送油要求により送油時間帯と送油量が
決まっている.すなわち, これらは操業スケジューリング 問題に対してはあらかじめ与えられた条件になる。タン カーのバースへの割当ては決まってなく, スケジューリン グで決定する因子である。なお，これ以後は揚油と夕ン カーを同一視して扱い，とくに言及する必要のある場合 にのみタンカーと明記することにする。送油に際しての タンク群選択にはとくに考慮する点はないので, 先入れ 先出しの原則に従い, 受け入れた順に払い出すタンクを 選択するものとする.しかし, 受入れについては, 受け 入れるベきタンクを受入れ可能なタンクの中から自由に 選ぶことができる. 各タンクは送油によって空になった後 は 3 時間の静置で受入れ可能になるので, その日の途中 から受入れ可能となるタンクがあり得る. 一方, 受入れ によって満になった後の払出しまでの静置時間は 24 時間 であるから，その日に払出しを行うタンクは前日までに 受入れを終了しているタンクである。したがって, 前日 までのスケジューリング結果が既知であるとすると，そ の日のスケジュールに必要なデー夕はすべて決まってし まう。したがって, 1 週間から 1 月間のスケジュールを 1 日単位で前から順番に作成していくことにすれば, 最 適性の保証はできないが, 実用上有効な結果を得ること ができると期待される。なお，スケジューリングの目的 は 1 日ごとの揚油時間带の中でのバースとタンク群対応 の変更回数を最小にすることであって，2 日以上にまた がるものではない.

1 日あたりのスケジューリングのアルゴリズムを記述 するため, 以下の記号を導入する.

記号

スケジューリングに際して与えられるもの

$N$ : 揚油の数

$M:$ タンク群の数

$J:$ 揚油のグループ数 
$Y_{n}$ : 揚油 $n$ の揚油量

$t_{n}$ ：揚油 $n$ の開始時刻，一般性を失うことなく, $t_{1} \leqq t_{2} \leqq \cdots \leqq t_{N}$ を仮定する。

$W_{m}(t)$ : スケジューリング開始時の時刻 $t$ でのタン ク群 $m$ の受入れ可能量

変数

$I_{n}$ ：揚油 $n$ に割り当てられたタンク群の個数 $m(n, i)$ : 揚油 $n$ に割り当てられたタンク群の中で時 間順に $i$ 番目のタンク群, $i=1, \cdots, I_{n}$ $d(n, m)$ ：揚油 $n$ のうちタンク群 $m$ に割り当てた量 $n=1, \cdots, N, m=1, \cdots, M$

スケジューリング開始時のタンク群 $m$ の受入れ可能量 $W_{m}(t)$ は, 送油終了後の静置制約をクリアして当日あら たに受入れ可能となるタンクの存在を無視すれば，タン ク群 $m$ に属する各タンクの前日の最終在庫量から決ま り，時間的に一定である。実際には，当日あらたに受入 れ可能となるタンクが存在する場合があり，その場合に はある時刻で受入れ可能となったタシクの容量が付加さ れるので, $W_{m}(t)$ は単調非減少な階段関数である.

これらの準備のもとに，本スケジューリング問題を定 式化する。

【1 日あたりのスケジューリング問題】

(1) バース割当て

各揚油に，そのタンカーが着栈可能なバースを一つず つ割り当てる。揚油中にバースを替えることはしないの で, 割り当てられるバースは一つずつである。

(2) タンク群割当て

各揚油はどれかのタンク群に割り当てて完全に終了さ せなければならない。すなわち，

$$
\sum_{i=1}^{I_{n}} d(n, m(n, i))=Y_{n}, n=1, \cdots, N
$$

ただし，タンク群への受入れには限界があるから，

$$
\sum_{i=1}^{n} d(i, m) \leqq W_{m}\left(t_{n}\right), n=1, \cdots, N, m=1, \cdots, M(2)
$$

(3) 目的関数

目的はバースとタンク群対応の変更回数を最小にす ることである。バースとタンク群の対応が時間的な意味 で前の対応と変わる可能性には二つの場合がある。あ る揚油 $n$ にバースは $k(n)$ を割り当て, タンク群は $m(n, 1), \cdots, m\left(n, I_{n}\right)$ を割り当てたとすると, バース $k(n)$ と最初のタンク群 $m(n, 1)$ の対応が前の対応と異なる場合 が第一の場合であり，揚油 $n$ の途中でタンク群を $m(n, 1)$ から $m(n, 2), \cdots, m\left(n, I_{n}\right)$ に切り換えていく場合が第二の 場合である。バースとタンク群対応の変更が発生すると, 運転員が現場に出てバースとタンク群を結ぶ配管系を新
しい対応を実現するようにいくつかのバルブを切り換え る操作が必要となり手間がかかる。第二の場合はこれが 揚油中に発生するから，配管系の操作の手間だけでなく タンカーの出航を遅らせることになる。また，揚油中に タンク群を切り換えるとき，その時点で切換え先のタン ク群が別のバースから揚油中のときはそれが終了するま で待たなければならず，ますますタンカーの出航を遅ら せることになる。一方，第一の場合は揚油 $n$ を開始する 前のほかの揚油の影響を考慮した適当な時点で配管系の 操作をすればよい。したがって，バースとタンク群対応 の変更が発生する場合でも，第一の場合が望ましく第二 の場合は極力避けたいのである。このような評価を実情 に合う形で目的関数として表現するのは容易ではないが, 第一の場合で発生するバースと夕ンク群対応の変更回数 を $f(n)$ とすると, 第二の場合で発生するバースとタン ク群対応の変更回数は $I_{n}-1$ であるから，たとえば，つ ぎのような表現が考えられる。

$$
\text { 目的関数 }=\sum_{n=1}^{N}\left\{\alpha_{1} f(n)+\alpha_{2}\left(I_{n}-1\right)\right\}
$$

ここに， $\alpha_{1}$ と $\alpha_{2}$ はそれぞれ第一の場合と第二の場合に 対応する重みである。

\section{4. 解法}

\section{1 基礎となる考え方}

3. で定式化した組合せ最適化問題は, 整数群の分割問 題であるPARTITION を特別な場合として含んでいるの で，明らかにNP困難であり2)，常に厳密解を効率良く 求める解法は期待できない。したがって，ここでは実用 性のある近似解法を考える。そのために，本問題のいく つかの性質を考察する。

毎日，揚油には揚油量の大きな揚油から小さい量の揚 油まであり，受入れ側のタンク群にも受入れ可能量の大 きなものから小さいものがある。もし，揚油量の小さな 揚油から順にタンク群に割り当てていくとすると, 割当 てが進んでいくにしたがって各タンク群の受入れ可能量 は小さくなっていくから，揚油量の大きな揚油に割当て るときに, 各タンク群の受入れ可能量の中にこの揚油量 以上のものが残っていない恐れがある。揚油量がタンク 群の受入れ可能量を上回っている場合は, 揚油途中で夕 ンク群切換えが必要となるので, これは極力避けたい事 態である.

つぎの二つのアイディアは，このような状況を避ける ことをねらいとしたものである。

1) 揚油量の大きな揚油から順に割り当てる.

2) 揚油をタンク群に割り当てるときは, 割り当てた結 果のタンク群受入れ可能量が最小になるタンク群を 
選ぶ.

スケジューリングの初期, すなわちタンク群を割り当 てる初期の段階では受入れ可能量の大きなタンク群が存 在するはずであるし, 後半の段階で各夕ンク群の受入れ 可能量が小さくなってきた状況でも，受け入れるべき揚 油量が小さければ, タンク群切換えなしで受入れできる 可能性が高いであろうというのがアイディア 1)の根拠で ある.また，割当てによって各タンク群の受入れ可能量 を均等になるように減らしていくと, スケジューリング のどこかの段階で受入れ可能量が揚油量を上回るタンク 群が残らなくなる危険性が高い. それに反し, 受入れ可 能量の大きなタンク群をできるだけ残すようにすればこ の危険性が小さくなるというのがアイディア 2)の根拠で ある。本論文のアルゴリズムはこの二つのアイディアを 基にしており, 欲張り法の一種である.

\section{2 アルゴリズムで用いる定義・操作}

アルゴリズムの中で用いる概念を以下に定義する.

【定義 1】タンク群の空容量

タンク群 $m$ の時刻 $t$ における空容量 $U_{m}(t)$ とは, 夕 ンク群 $m$ に属する受入れ可能なタンクの時刻 $t$ での（容 量一在庫量) の和である.

【定義 2】タンク群の受入れ可能量

タンク群 $m$ の時刻 $t$ における受入れ可能量 $V_{m}(t)$ と は, その日の時刻 $t$ 以後のすべての時刻におけるタンク 群 $m$ の空容量 $U_{m}$ の最小值である.すなわち,

$$
V_{m}(t)=\min _{t \leqq \tau} U_{m}(\tau)
$$

である。したがって, $V_{m}(t)$ は $t$ に関して単調非減少な 関数である.

スケジュール作成においては, $W_{m}(t), U_{m}(t)$ および $V_{m}(t)$ の情報は揚油を開始する離散的時刻 $t_{n}$ において のみ必要となるので, それらの時点における值のみを保 持すればよい，その理由は，このアルゴリズムが作るス ケジュールでは, 揚油中のタンク群切換えを（基本的に は）許さないので, 揚油 $n$ がタンク群 $m$ に受入れ可能 かどうかは時刻 $t_{n}$ におけるタンク群 $m$ の受入れ可能量 だけから決定できるからである. (タンク群 $m$ が揚油 $n$ を受け入れ始めた後, $t_{i-1}<t \leqq t_{i}$ を満たす時刻 $t$ で終 了したとしても, スケジューリングに必要となるのは時 刻 $t_{i}$ における情報である.)

$U_{m}\left(t_{n}\right)$ と $V_{m}\left(t_{n}\right)$ は, スケジューリングの開始時は 等しいが (その值が $W_{m}\left(t_{n}\right)$ である)，スケジューリ ングの進行とともに部分的にスケジュールされた結果に 合わせて更新されるので，一般には両者は等しくなく， $W_{m}\left(t_{n}\right) \geqq V_{m}\left(t_{n}\right)$ の関係にある.
【定義 3】揚油時間のオーバーラップ

配船計画から揚油 $n=1, \cdots, N$ の開始時刻 $t_{n}$ と揚油量 $Y_{n}$ は決定している. 各バースにおける揚油速度は等しい ので, 揚油の途中でタンク群切換えをしなければ揚油 $n$ の終了時刻 $s_{n}$ がわかる. 揚油 $n$ の時間区間 $\left[t_{n}, s_{n}\right]$ が ほかの揚油 $l$ の時間区間 $\left[t_{l}, s_{l}\right]$ と共通部分をもつとき, 揚油 $n$ と $l$ は時間がオーバーラップしているという.

【定義 4】揚油 $n$ がスケジューリングのある段階で バース $k$ に割当て可能であるとは, 揚油 $n$ のタンカーが バース $k$ に着栈可能で, かつ揚油 $n$ と時間がオーバー ラップしているどの揚油もバース $k$ に割当て済みでない ことをいう.

【定義 5】揚油のグループ分け

着栈可能なタンカーの大きさによりバースがグループ 化されることに対応して, 揚油を揚油量の大きい方から $H_{1}, H_{2}, \cdots, H_{J}$ とグループ化する. $J$ はバースのグルー プ数であったが, 揚油のこのグループ分けにより, 揚油 のグループ数でもある. 揚油グループ $H_{j}$ がたとえば揚 油量 $1000 \mathrm{KL}$ 以上 $2000 \mathrm{KL}$ 未満に対応するとすると, 揚 油 $i \in H_{j}$ に対応するタンカーは $1000 \mathrm{KL}$ 以上のタンカー が着栈できるバースにしか着栈できない.バースグルー プがバースの大きいもの順に番号を付けられているとす ると, 揚油 $i \in H_{j}$ は $j$ 以下の番号のバースグループに属 するバースに着栈可能である. $N_{j}$ を $H_{j}$ に属する揚油 の個数とすると, $H_{j}=\left\{n_{j 1}, n_{j 2}, \cdots, n_{j N_{j}}\right\}$ と書ける.

【定義 6】グラフ $G_{j}$ グラフ $G_{j}=\left(V_{j}, E_{j}\right)$ はグループ $H_{1}, H_{2}, \cdots, H_{j}$ のオ ーバーラップ関係を表すもので, 節点集合 $V_{j}=\left\{n_{p q} \mid p=\right.$ $\left.1,2, \cdots, j ; q=1,2, \cdots, N_{p}\right\}=H_{1} \cup H_{2} \cup \cdots \cup H_{j}$ をもち, $V_{j}$ の揚油 $n_{p q}$ と $n_{p^{\prime} q^{\prime}}$ がオーバーラップするとき, 枝 $\left(n_{p q}, n_{p^{\prime} q^{\prime}}\right) \in E_{j}$ をもつ. ただし, 揚油 $n_{p q}$ と $n_{p^{\prime} q^{\prime}}$ が ともにバースを割当て済みのときは枝を結ばない.

【定義 7】 $r$-クリーク

グラフ $G_{j}$ において，その中の任意の 2 節点が枝で接 続されているような $r$ 個の節点からなるクリーク3)を $r-$ クリークという.

タンク群の空容量 $U_{m}\left(t_{n}\right)$ と受入れ可能量 $V_{m}\left(t_{n}\right)$, お よび割当て可能バース集合については，アルゴリズムの 中でスケジューリングの進行とともに更新されていく.こ の更新操作を以下に述べる.

【操作 1】空容量・受入れ可能量の更新

揚油 $n$ へのタンク群割当ての結果, タンク群 $m$ が時 刻 $t_{n}$ で量 $v$ を受け入れることになったとする。このと き, タンク群 $m$ の空容量をつぎのようにして更新する. 更新前のタンク群空容量を $U_{m}\left(t_{i}\right)$, 更新後のタンク群空 容量を $U_{m}^{\prime}\left(t_{i}\right)$ とすると, 


$$
U_{m}^{\prime}\left(t_{i}\right)= \begin{cases}U_{m}\left(t_{i}\right) & ; 1 \leqq i \leqq n-1 \\ U_{m}\left(t_{i}\right)-v & ; n \leqq i \leqq N\end{cases}
$$

である.その結果, タンク群 $m$ の受入れ可能量はつぎ のように更新される。更新前のタンク群受入れ可能量を $V_{m}\left(t_{i}\right)$, 更新後のタンク群受入れ可能量を $V_{m}^{\prime}\left(t_{i}\right)$ とす ると

$$
V_{m}^{\prime}\left(t_{i}\right)= \begin{cases}V_{m}\left(t_{i}\right)-v & ; n \leqq i \leqq N \\ \min \left\{V_{m}\left(t_{i}\right), V_{m}^{\prime}\left(t_{n}\right)\right\} & ; 1 \leqq i \leqq n-1\end{cases}
$$

である。

【操作 2】割当て可能バース集合の更新

スケジューリングのある段階で, 揚油 $n$ がバース $k$ に 割り当てられたとする。このとき，バースの割当てがまだ 済んでいない揚油 $i$ について, 割当て可能バース集合を つぎのようにして更新する．更新前および更新後の揚油 $i$ の割当て可能バース集合をそれぞれ $\Omega_{i}, \Omega_{i}^{\prime}$ とすると,

$$
\Omega_{i}^{\prime}= \begin{cases}\Omega_{i}-k & ; \text { 揚油 } i \text { と } n \text { の時間がオーバーラップ } \\ \Omega_{i} \quad ; \text { そうでない }\end{cases}
$$

なお, $\Omega_{i}$ の初期值は $i \in H_{j}$ のとき, グループ $H_{j}$ の揚 油（正確にはそのタンカー）が着栈できるすべてのバー スの集合 $\Psi_{j}$ に設定しておく.

\section{3 アルゴリズム}

本論文のアルゴリズムはつぎのようにまとめられる. アルゴリズム中に現れるバース・タンク群割当てルール とタンク群割当ての修正については, 後で説明する.ま た，アルゴリズム中にすべての極大クリークを抽出する 部分があり， $N$ が大きくなりグラフが密であれば極大 クリークの数は指数関数的に増大するから（極大クリー クをすべて列挙するアルゴリズムについては，たとえば 参考文献 4),5)），本アルゴリズムは実用性を失う。しか しながら, 本対象においてグラフが密になるということ は，すべてのバースにタンカーが着船し，さらに後から 到着したタンカーがいくつかのバースで前のタンカーの 処理を待つという込み合った状況に相当するので, その ような運用はなされないはずであり, したがって, 実際 に生じる具体例ではそのような事態には至らないと考え ている。

\section{step 1 初期設定}

1) 各タンク群の空容量と受入れ可能量の初期値 $W_{m}\left(t_{n}\right)$ を求める.

2) 揚油 $n=1, \cdots, N$ を揚油量の大きい順にグ ループ $H_{1}, H_{2}, \cdots, H_{J}$ に分ける.

3) 揚油 $n=1, \cdots, N$ の割当て可能バース集合 $\Omega_{n}$ を求める.

4) $j:=1$ とする. step 2 グラフ $G_{j}$ の作成と極大クリークの抽出 グラフ $G_{j}$ を作成し, $G_{j}$ の極大クリーク $C_{1}$, $\cdots, C_{s}$ をすべて求める. グラフ $G_{j}$ に節点が存 在しなければstep6に行く.

step 3 クリークの選択

クリーク $C_{1}, \cdots, C_{s}$ の中から,

(1) $\min _{n \in C}\left|\Omega_{n}\right|-r\left(C_{s}\right)$ が最小のクリーク $C_{s}$ を 選ぶ.ここに, $r\left(C_{s}\right)$ はクリーク $C_{s}$ の節点 数である.

(2) 条件(1)を満たすクリークが複数あるときは, $\min _{n \in C_{s}}\left|\Omega_{n}\right|$ が最小のクリーク $C_{s}$ を選ぶ.

(3) 条件(2)を満たすクリークが複数あるとき $\sum_{n \in C_{s}}\left|\Omega_{n}\right|$ が最小のクリーク $C_{s}$ を選ぶ.こ れが複数あるときは，どれか一つを自由に 選ぶ。ただし，条件(1)，(2)，(3)，における 評価対象となる揚油 $n$ は，バースを割当て 済みでない揚油とする。

\section{step 4 揚油の選択}

選ばれたクリーク $C_{s}$ の中のバースを割当て済 みでない揚油の中から, $\left|\Omega_{n}\right|$ の最小の揚油 $n$ を 選ぶ. $\left|\Omega_{n}\right|=0$ は, 割り当てることのできるバー スがないということであり，これは元の問題が実 行可能でないことを意味するから, $\left|\Omega_{n}\right|>0$ の はずである。

step 5 バースとタンク群割当て

選ばれた揚油 $n$ に, 4.3.1に記述するバース・夕 ンク群割当てルールに従いバースとタンク群を 割り当てる.そして, タンク群空容量, 受入れ可 能量, 割当て可能バース集合を更新する。この クリークの中にバースを割当て済みでない揚油 が残っていればstep4に戻る。残っていなければ step2 に戻る.

step $6 \quad j:=j+1$ とする. $j>J$ なら step7へ行く. $j \leqq J$ なら step2へ戻る。

step 7 タンク群の空容量の中に負の值がなければ終了 する.そうでないときは, 4.3.2 に記述する夕 ンク群割当ての修正の手順を実行した後，終了 する。

4.3.1 揚油 $n$ のバース・タンク群割当てルール アルゴリズムの step5 で用いたバースとタンク群割当 てルールを以下に示す.

【ルール 1】

揚油 $n$ を受入れ可能なタンク群との結合がすでに済ん でいるバース $\in \Omega_{n}$ があれば，そのバースを割り当てる.

【ルール 2 】

ルール 1 に適合するバースが複数あるときは，割り当 
てた結果のタンク群受入れ可能量 $(\geqq 0)$ が最小になる バースを選ぶ。

\section{【ルール 3】}

ルール 1 に適合するバースが存在しないとき，すなわ ち, タンク群との結合が済んでいないバース $\in \Omega_{n}$ に割 り当てるときは, バース $\in \Omega_{n}$ は自由に選び, 割り当て た結果のタンク群受入れ可能量 $(\geqq 0)$ が最小になるタン ク群と結合する。

$$
\text { 【ルール } 4 \text { 】 }
$$

ルール 3 でタンク群受入れ可能量が負になる場合は, 負の量が最小になる場合を選択する.

\subsection{2 タンク群割当ての修正}

アルゴリズムの step7に進んだ段階では，すべての揚 油にバースとタンク群が一つずつ割り当てられている. このときのタンク群の空容量 $U_{m}\left(t_{n}\right), m=1, \cdots, M$, $n=1, \cdots, N$ の中に負の值が存在しなければ，この割当 てがバースとタンク群対応の変更回数 0 の最適解である. 負の值が存在する場合, たとえば, タンク群 $m$ におい て, 時刻 $t_{1}, \cdots, t_{N}$ に対し $U_{m}\left(t_{n}\right)$ が最初に負になった とすると,これは揚油 $n$ をタンク群 $m$ に受け入れたと きそこでオーバーフローが発生することを示しているの で,この割当ては害行可能解ではない. したがって, こ のような場合には, タンク群の割当てを修正する必要が ある。この修正は時間軸に沿って以下の手順で行う.

step 1 初期設定

$n:=1$

step 2 タンク群空容量 $U_{m}\left(t_{n}\right), m=1, \cdots, M$ の中に負 の值があれば step3に，なければstep5に行く.

step 3 タンク群空容量が負のタンク群を $m$, すなわち, $U_{m}\left(t_{n}\right)<0$ とする. 揚油 $n$ に割当て可能なタン ク群は, 揚油 $n$ とオーバーラップしている揚油 に割り当てられたタンク群を除いたタンク群で ある. $m$ を除く割当て可能なタンク群の中から, 揚油量 $Y_{n}$ を引いても $U_{l}\left(t_{n}\right)<0$ とならない夕 ンク群 $l$ を選ぶ.このタンク群が存在しない場 合はstep4に行く．存在する場合は，揚油 $n$ に 対するタンク群割当てをタンク群 $m$ から $l$ に修 正するとともに，タンク群空容量も修正し step5 に行く.もし, タンク群 $l$ の候補が複数あるとき は，つぎのルールに従って一つ選ぶ.

(1) 修正後のタンク群空容量 $t_{n}$ より先の時刻 で負にならないタンク群のうち, 先の時 刻でのタンク群空容量の最小值が一番小 さいタンク群を選ぶ.

(2) ルール(1)に適合するタンク群が存在しな い場合は, 修正後のタンク群空容量が負
になる時刻が最も遅いタンク群を選ぶ.

step $4 m$ を除く割当て可能なタンク群の中から, タン ク群 $m$ のオーバーフロー量 $-U_{m}\left(t_{n}\right)$ を引いて も $U_{l}\left(t_{n}\right)<0$ とならないタンク群 $l$ を選ぶ.こ のタンク群が存在しない場合は実行不能として 終了する。二つ以上存在するときは, step3 と同 ビルールに従い一つ選ぶ. この結果, 揚油 $n$ に 最初にタンク群 $m$ が受け入れ, つぎにタンク群 $l$ が受け入れるというように, タンク群割当てと タンク群空容量を修正し step5に行く.

step $5:=n+1$ とし, $n>N$ なら終了. $n \leqq N$ なら step2 に戻る.

バースとタンク群対応を変更する場合は, タンカーの 出航をできるだけ遅らせないという観点から, 変更に伴 う施設内配管のバルブ操作を切換えが必要となった揚油 の開始前に行うことが望ましい. step3 はこの切換えに 対応し, どうしても揚油中に切り換えるしかほかに方法 がなければ揚油中の切換えを 1 回だけ認めるというのが step4である.

\section{5. 実証結果と評価}

給油施設の具体例として, 四つのバース, 四つのタン ク群を有する実在の設備を考察する。なお，スケジュー リングに直接には影響しないが, 送油パイプラインは 2 系統ある. 各バースに着栈可能なタンカーは Table 1 の とおりであり,これに対応して揚油量は $8000 \mathrm{KL}, 3000-$ 4000KL, 2000KLの 3 ランクに分けられる. 各タンク群 に属するタンクの大きさと個数は Table 2 のとおりであ る.すなわち, この設備では, $K=4, M=4$ である.

この給油施設を通して本アルゴリズムの働きとその 結果を説明する。まず，配船計画からある日の揚油スケ ジュールがFig. 2 のように与えられたとする.これより， 揚油数 $N=9$, 揚油グループ数 $J=3$ であり,

$$
H_{1}=\{6\}, H_{2}=\{2,3,4,7,8\}, H_{3}=\{1,5,9\}
$$

Table 1 Grouping of tankers by berths

\begin{tabular}{|c|c|c|c|}
\hline $\begin{array}{r}\text { Tanker } \\
{[\mathrm{KL}]}\end{array}$ & 2000 & $\begin{array}{c}3000 \\
- \\
4000\end{array}$ & 8000 \\
\hline 1 & $\bigcirc$ & $\times$ & $\times$ \\
\hline 2 & $\bigcirc$ & $\bigcirc$ & $\times$ \\
\hline 3 & $\bigcirc$ & $\bigcirc$ & $\bigcirc$ \\
\hline 4 & $\bigcirc$ & $\bigcirc$ & $\bigcirc$ \\
\hline
\end{tabular}




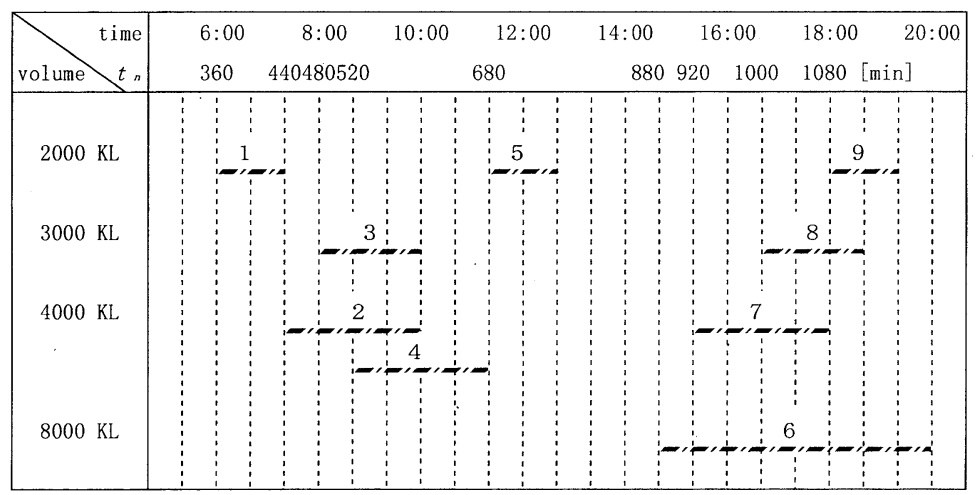

Fig. 2 Fuel unloading schedule

Table 2 Capacities of tank groups

\begin{tabular}{|c|l|c|c|}
\hline $\begin{array}{l}\text { tank } \\
\text { group }\end{array}$ & $\begin{array}{l}\text { capacity } \\
\text { of tank }\end{array}$ & $\begin{array}{c}\text { number } \\
\text { of tank }\end{array}$ & $\begin{array}{c}\text { capacity of } \\
\text { tank goup }\end{array}$ \\
\hline 1 & $3000[\mathrm{KL}]$ & 3 & $9000[\mathrm{KL}]$ \\
\hline 2 & $9000[\mathrm{KL}]$ & 2 & $18000[\mathrm{KL}]$ \\
\hline 3 & $3000[\mathrm{KL}]$ & 3 & $9000[\mathrm{KL}]$ \\
\hline 4 & $9000[\mathrm{KL}]$ & 2 & $18000[\mathrm{KL}]$ \\
\hline
\end{tabular}

である.さらに，オーバーラップしている揚油集合は，

$$
\{2,3,4\},\{6,7,8\},\{6,8,9\}
$$

である。また, 前日のタンク在庫量と状態遷移から, そ の日の最初の揚油開始時点での各タンク群の受入れ可能 量 $W_{m}\left(t_{1}\right)$ が

0KL，9000KL，3000KL，9000KL

であったとする。これに前日および当日の送油スケジュ ールから，その日の途中で新たに受入れ可能となるタン クが,

揚油(2)と(3)の間で, タンク群 1 の 1 基 揚油(5)と(6)の間で, タンク群 2 の 1 基 揚油(5)と(6)の間で, タンク群 3 の 1 基

発生するとすれば, タンク群の受入れ可能量の初期值 $W_{m}\left(t_{n}\right)$ が Table 3 のように得られる。これらの前提 条件のもとでアルゴリズムを適用すると, グラフ $G_{j}$ と して Fig. 3 に示す $G_{1}, G_{2}, G_{2}, G_{3}, G_{3}, G_{3}$ がこの順で 作られ, 各グラフ $G_{j}$ の中には Fig. 3 に示すクリークが
存在する.Fig. 3 はこれらのクリークが処理される順番 も示して扮り, 最終的に Table 4 に示すタンク群切換え を必要としない最適解が得られる。

つぎに本アルゴリズムの性能を調べるため, 同じ問題 をほかの方法によって解くことを試みた結果を Table 5 に示す.クリークを利用して必ずしも揚油順ではない順 序で割当てを行っていく本アルゴリズムに対比するもの として，揚油順に割当てを行うという考え方があり，これ はわかりやすくかつ自然なアイディアではある. Table 5 の方法 1-3 はこのアイディアに基づいている.

Table 5 の方法 1 は, 各揚油にタンク群を割り当てる とき, 受入れ可能量が最大のタンク群を選ぶ方法である. この方法で揚油 1-3にバースとタンク群を Table 5 のよ うに割り当てたとすると, 揚油 2 と 3 と 4 がオーバーラッ プしていることから, 揚油 4 に割り当てるべきバースは 4 に決まる. 揚油 4 の揚油量は $4000 \mathrm{KL}$ であることから， この時点で受入れ可能量が $4000 \mathrm{KL}$ を上回っている夕ン ク群 2 と 4 の中から揚油 4 に割り当てるべきタンク群を 選ばなければならない.ところが, タンク群 2 も 4 もこ の時点ですでにバース 4 以外のバースと対応関係がつい ているため, どちらを選んでも切換えが発生し,この結 果は最適ではない.

Table 5 の方法 2 は, まず本論文のアルゴリズムと同 様に揚油のグループ分けを行い, 揚油 $n \in H_{j}$ にタンク 群を割り当てるとき, その時点で受入れ可能なタンク群 の中から受入れ可能量が $j$ 番目の大きさのタンク群を選 ぶ方法である.その時点で受入れ可能量が等しいタンク 群が複数個ある場合は後の時刻で受入れ可能量の増える 量に応じて順位をつける。この方法では, 揚油 $1 \sim 6$ まで 切換えのない割当てができる. 揚油 7 に対しては, 揚油 量 $4000 \mathrm{KL}$ をその時点で上回るタンク群 2 と 3 が割当て 
Table 3 Initial receivable volumes to tank groups $W_{n}\left(t_{n}\right)[\mathrm{KL}]$

\begin{tabular}{|c|rrrrrrrrr|}
\hline fuel unloading & \multicolumn{1}{|c}{1} & \multicolumn{1}{c}{2} & 3 & \multicolumn{1}{c}{4} & \multicolumn{1}{c}{5} & \multicolumn{1}{c|}{6} & \multicolumn{1}{c|}{8} & \multicolumn{1}{c|}{9} \\
\hline$t_{n}$ [min] & 360 & 440 & 480 & 520 & 680 & 880 & 920 & 1000 & 1080 \\
\hline tank group 1 & 0 & 0 & 3000 & 3000 & 3000 & 3000 & 3000 & 3000 & 3000 \\
tank group 2 & 9000 & 9000 & 9000 & 9000 & 9000 & 18000 & 18000 & 18000 & 18000 \\
tank group 3 & 3000 & 3000 & 3000 & 3000 & 3000 & 6000 & 6000 & 6000 & 6000 \\
tank group 4 & 9000 & 9000 & 9000 & 9000 & 9000 & 9000 & 9000 & 9000 & 9000 \\
\hline
\end{tabular}

G1 6) $\quad\{6\}: 1-$ clique

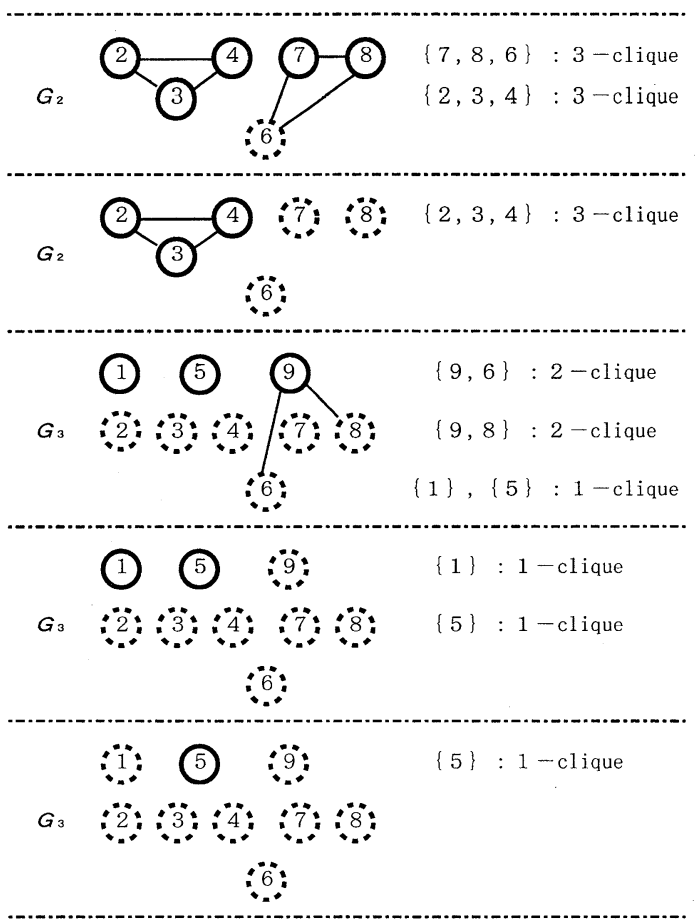

$\because n$ : fuel unloading $n$ to which a berth and a tank group have been already assigned

Fig. 3 Graph $G_{j}$ s appeared in an example problem

可能である。このうち, タンク群 3 を割り当てると対応 するバースが 1 に決まるが，揚油 7 のタンカーはバース 1 には着栈できないのでこの割当ては実行可能ではない. タンク群 2 を割り当てると揚油 7 に対する割当てが揚油 6 と同じになり，これは揚油 6 と 7 と 8 がオーバーラップ していることから実行可能ではない.

Table 5 の方法 3 は, 基本的には方法 2 と同じである
Table 4 Optimal solution

\begin{tabular}{|c|c|c|c|c|c|c|c|c|c|}
\hline fuel unloading No. & 1 & 2 & 3 & 4 & 5 & 6 & 7 & 8 & 9 \\
\hline berth No. & 4 & 4 & 2 & 3 & 4 & 4 & 3 & 2 & 1 \\
\hline tank group No. & 2 & 2 & 3 & 4 & 2 & 2 & 4 & 3 & 1 \\
\hline
\end{tabular}

Table 5 Results by other methods

\begin{tabular}{|c|l|c|c|c|c|c|c|c|c|c|}
\hline \multicolumn{2}{|c|}{ fuel unloading No. } & 1 & 2 & 3 & 4 & 5 & 6 & 7 & 8 & 9 \\
\hline \multirow{2}{*}{$\begin{array}{c}\text { method } \\
1\end{array}$} & berth No. & 1 & 3 & 2 & - & - & - & - & - & - \\
\cline { 2 - 10 } & tank group No. & 2 & 4 & 3 & - & - & - & - & - & - \\
\hline \multirow{2}{*}{$\begin{array}{c}\text { method } \\
2\end{array}$} & berth No. & 1 & 3 & 2 & 4 & 3 & 4 & - & - & - \\
\cline { 2 - 10 } & tank group No. & 3 & 4 & 1 & 2 & 4 & 2 & - & - & - \\
\hline \multirow{2}{*}{$\begin{array}{c}\text { method } \\
3\end{array}$} & berth No. & 1 & 3 & 2 & 4 & 4 & 3 & - & - & - \\
\cline { 2 - 10 } & tank group No. & 3 & 4 & 1 & 2 & 2 & 4 & - & - & - \\
\hline
\end{tabular}

が，方法 2 における揚油 5 の割当てを修正したものであ る.この修正により, 揚油 7 に対しても実行可能かつ切 換えのない割当てができる。揚油 6 と 7 と 8 がオーバー ラップしていることから，このとき揚油 8 に割り当てる ベきバースは 2 に決まる。そうすると切換えをしないた めにはタンク群 1 を割り当てなければならないが, この 時点でタンク群 1 の受入れ可能量は $0 \mathrm{KL}$ であるから, 必 然的に切換えが発生する。すなわち,この結果は最適で はない.

方法 1-3において，揚油の中には割り当てるべきバー スに複数の可能性がある場合がある。したがって，実行 不能になったり切換えが発生する割当てになった場合は, 別のバースを割り当てることのできる揚油に戻り，バー スを修正してその揚油以後の揚油に対する再割当てを行 うという方法は考えられる。ただし，このような方法は 計算効率という点からはうまい方法とはいえない.

以上, 本アルゴリズム以外の方法として方法 $1 \sim 3$ を考 察し, 本論文の例の問題に対しては最適解を得ることが 
難しいことを示した.

スケジューリングのある段階で切換えなしのバース・ タンク群割当てができなくなるのは, 主につぎの二つの 場合である。

（場合 1) 受入れ可能量の大きなタンク群が残っていな w場合.

(場合 2) 受入れ可能量の大きなタンク群が少し残って はいるが，すでに割り当てられたバースと夕 ンク群の対応関係からそのようなタンク群に 割り当てることができない場合.

揚油量の大きな揚油をスケジューリングの後半に割り 当てるときには場合 1 に該当する可能性が高いし，時間 がオーバーラップしている揚油の組を割り当てるときに は場合 2 に該当する可能性が高い. 実際, 方法 2 と 3 で は揚油の組 $(6,7,8)$ のときに, 場合 2 にひっかかってお $\eta$, 方法 1 ではさらに早い段階の揚油の組 $(2,3,4)$ のと きに場合 2 にひっかかっている．他方，本アルゴリズム には三つの大きな特徵

（特徵 1）揚油量の大きい揚油順に割り当てる

（特徴 2) 割当て後の受入れ可能量の大きいタンク群に 割り当てる

（特徵 3）極大クリークの利用

があり, 場合 1 や場合 2 が起きるのを回避していると考 えられる.すなわち, 特徵 1 によりスケジューリングの 後半で割り当てる揚油は揚油量が小さいので, 場合 1 が 起きたとしても割当てができる。また，特徵 2 により場 合 1 が発生する危険性を緩和している。 そして, 特徵 3 によりバース選択の自由度の小さい揚油を先に割り当て ているので, 場合 2 が起こりにくい.

なお，この設備の操業スケジューリングを作成する現 行のシステムでは, 揚油順に実行可能解を探索する前述 の方法 1-3 に類似のアルゴリズムが稼働中である．その システムで作成したある 1 週間のスケジュール（1 日あ たり 4-5揚油, 1 週間で 32 揚油) の中に, タンク群切換 えを必要とする日が 2 日あった。このデータに対し， 1 週 間のスケジュールを本アルゴリズムを用いて作成したと ころ,すべての日においてタンク群の切換えを必要とし ない最適解が得られた。

このことから，本アルゴリズムを実操業に適用すれば， 通常の状況では夕ンク群の切換えを必要としない最適解 が得られると期待できる。もちろん，本アルゴリズムに よっても，切換えが発生する可能性があるが，そのとき にはそれまで作成したスケジュールを部分修正して操業 上望ましいスケジュールを与える工夫をしている。 それ が4.3.2のタンク群割当ての修正である.このような夕 ンク群の割当て修正が必要となるのは，おおざっぱに言
えば, タンク群受入れ可能量の総和と揚油量の総和の差 が小さいときであるが, 実設備では原則としてそのよう な余裕のない操業はしないので, この 4.3.2の修正機能 を必要とする場合はまれではないかと考えられる.

\section{6. おわりに}

給油施設の操業スケジューリング問題は NP 困難な組 合せ最適化問題であり, 制約の厳しい場合も含め, 常に 厳密解を効率良く求めることは期待できないが, 問題の 特徵を利用することにより, 良い解 (多くの場合最適解) の得られるヒューリスティックアルゴリズムを開発した。 本アルゴリズムは，バースやタンク群の設備数に一般性 をもたせているので, 現状の設備での運用スケジューリ ングだけでなく, 将来の設備拡張などの検討にも利用可 能である.

おわりになりましたが, 本論文の審査の過程で, 査読 者の方から詳細かつ貴重な御意見を頂き, 記述の向上に 役立てることができた。ここに記して謝意を示します.

\section{参考文献}

1) 湊, 掛谷, 根津: 給油施設の能力評価と操業スケジューリン グ；NKK 技報, No. 153, pp. 106-113 (1991)

2) M. R. Garey and D. S. Johnson: Computers and Intractability: A Guide to the Theory of NPCompleteness, W. H. Freeman (1979)

3) F. Harary: Graph Theory, Addison-Wesley (1969)

4) S. Tsukiyama, M. Ide, H. Aiyoshi and I. Shirakawa: A new algorithm for generating all maximal independent sets; SIAM J. Computing, Vol. 6, pp. 505-517 (1977)

5) D. S. Johnson, M. Yannakakis and C. H. Papadimitriou: On generating all maximal independent sets; Information Processing Letters, Vol. 27, pp. 119-123 (1988) 
